\title{
Development of Emotional Quotient and Spiritual Quotient: The strategy of Ethics Development
}

\author{
Vahid Fallah ${ }^{1}$, Soheila Khosroabadi ${ }^{2 \star}$, Hamideh Usefi ${ }^{2}$ \\ ${ }^{1}$ Educational Planning, Faculty Member of Islamic Azad University Sari Branch \\ 2Educational Management, Islamic Azad University Sari Branch \\ *Email address: soheilakhosroabadi@yahoo.co
}

\begin{abstract}
This paper has investigated the importance of spiritual and emotional quotient in reinforcing the values of Islamic ethics. The development of good character in Islam is the process of encountering with individual feelings that contributes to the creation of and support of good and proper feelings such as forgiveness, compassion, love, generosity, and courage and fights against negative feelings such as envy, anger, selfishness and dastardliness and suppresses them. Character-making should do many works with patience and persistence in controlling feelings resulting in negative dimensions and reinforcing feelings resulting in positive ethics. Employing and controlling feelings will result in training deserved ethics. In addition, it leads a healthy spiritual and psychic life. New research show that individuals who reinforce their own spiritual motivations and have developed their own emotional quotient, are more inclined to achieve competitive advantage than those who have not this intelligence. The main objective of this research is to investigate a new field in modern psychology including emotional quotient and spiritual quotient that is aimed at whether new psychological approaches and positive findings of studying human emotions and feelings can contribute to the Islamic ethics or not.
\end{abstract}

Keywords: Emotional Quotient; Spiritual Quotient; Moral Virtues; Self-awareness; Self-control

\section{INTRODUCTION}

Examining past civilizations and societies shows that in no period, the need to moral and spiritual revolution was not felt like nowadays. Nowadays all claim that the major crisis of society particularly in the advanced industrial societies is moral crisis (Bleazby, 2006). Modern spirituality has made differences in modern human life through presenting different though. Teaching Islamic ethics as afield in the Islamic studies should not be limited to a theoretical or philosophical stance, but Muslims should learn the real application of ethics, which is extremely important in planning steady development if they expect the development of their own character and achievement of spiritual health and psychic logic (Abdifar \& Sorkhi, 2008; Zohar, 2005). Thus, teaching ethics is the primary goal of practical programs focusing on the modern moral problems.

On the one hand, spiritual quotient as the foundation of individual beliefs plays a crucial role in promoting and providing psychic health so that nowadays world health organization introduces human with four complementary dimensions of physical, psychic, social and spiritual. Many experts consider spiritual quotient as the guarantee for the highest levels of 
cognitive, moral and emotional growth and constant human's effort for answering his life whys (Ian Marshall \& Zohar, 2000; Becker, 2005). Therefore, when we speak of Islamic ethics, we discuss extremely wide fields of behavior that cannot be compressed into one unified concept such as emotional quotient. Researchers distinguish human moral values and spiritual ones that are accepted universally.

Moral principles such as patience, generosity, honesty and diligence are considered worthy in each culture, but when these values are enriched with the spiritual dimension of Islam, not only would be stronger and wider, but also lead religious rituals. One of the main reasons of the greatness of Islamic ethics is that it is inspired on the Muslim's heart. A real Muslim is someone who understands the reality of the problems of this world and use them for purifying and closing himself to the Exalted God (Allah) and finally receives the support and power of the one God, thus, he places patience as his heading in pursuit of good character and his Creator's satisfaction. Therefore, here we are encountered with two main questions attempting to answer them in this paper:

1. What is the role of spiritual and emotional quotient in the development of the virtues of Islamic ethics?

2. What are the different identity effects on forming spiritual and emotional quotient?

\section{MORAL VIRTUE AND INDIVIDUAL SELF-MAKING}

Moral principles includes individual self-making that is relevant with the management of emotions and psycho-spiritual health and social skills and is more coordinated with the characteristics of our age. On this basis, Islamic ethics teachings, from modern perspective, need the participation of classical Islamic ethics with modern accepted psychology (Zaroug, 1999). Scientists like Ghazali and Balkhi, the famous Islamic characters, have made all their efforts to reinforce their students' psychic spirituality and presented appropriate methods to purify their characters. When we combine spiritual principles and sublimity with modern social discipline, considering the Quran and the Prophet's character (peace be upon him) as a model can help humans to solve their modern social and individual problems.

We are faced with two approaches of moral principles in relation to the existence of human: moral virtues (piety) and moral deed in moral virtue. Morality is considered instead of person's deeds in his character and desires. In moral virtue, morality includes a way of life dealing with the purification of soul for the development and improvement of individual's character. This approach of self-viewing is the nature of moral virtue (Fakhry, 1991).

Spiritual virtue or morality is recognized as the psychology that deals with self-analysis and seeks to form human's character. Moral virtue is an accurate and comprehensive process that enables the individual to understand his psychic structure better and develop his relation with God. Human's nature and the psychology of his soul and the real structure of his character and existence are exposed to a deep reality that develops beyond our understanding. According to moral psychology, spiritual issues facilitate our achievement to the final goals in which individual can move in the path of his spiritual sublimity and provide us with a tool to discover who we are, where do we go and the what is the goal our life journey (Mohd, 2003). Moral teaching and education first need to purify itself, which is in relation with individual's life and performance not only in this world, but also in the other world (Tooranloo \& Mirghafuri, 2007).

The purification of soul is the prerequisite to be close to God. In fact, all moral and spiritual qualities depend on psychic purification. Human's inner relation with God as the foundation of morality not only gives human's deeds meaning and value, but also express his 
religious commitment that one of the main tasks of all prophets and the main goal of all their attempts have been helping people to purify their soul.

\section{EMOTIONAL QUOTIENT}

Emotional quotient (EQ) is a comprehensive concept of incomprehensible capacities, qualifications and skills that help individual to be more efficient in encountering with needs and environmental pressures. These factors directly affect a level of satisfaction, success, stressconfrontation ability, self-confidence, perception control and a high level of psychic health (Conscious, 2005). EQ refers to:

1. Individual's capacity for identifying his or others' feelings

2. Creating motivation in himself

3. Making right decision against stimulated emotions of himself or others (Goleman, 1997)

The dimensions of emotional and social intelligence include interpersonal and intrapersonal, compatibility and self-control, which are under four general abilities namely selfawareness, self-management, social awareness and relation management.

EQ is as a source of energy, information, relation and influence for human. An individual with high EQ is able to compatible with other individuals and different situations on the basis of positive attitude towards all life aspects and ability to attract respect through making this relation. EQ refers to a series of acquirable skills and qualifications that predicts positive results at home, family, workplace and society. Individuals with high EQ are often described as disciplined, warm-hearted, patient and positive. The inability of feelings management is considered as one of the main causes of stress and as a result conflict particularly when it includes interpersonal interactions and intergroup relations. EQ can help teaching Islamic ethics with new psychological approach and the results of studying human positive feelings and emotions. Certainly, it is extremely worthy, because the development of good character in Islam mostly is a process of good encounter with our and others' feelings. Some of the aspects of modern psychological including EQ can be employed as an effective method of managing feelings and emotions leading intrapersonal development and interpersonal relationship skills in designing character properly.

Findings concerning harming and aggressive students and those who abandon their education show that both groups have inefficient performance in EQ and indicate their low ability in confronting with stress and in being compatible with interpersonal and intrapersonal relations that is one of the components of EQ (Animasahun, 2010).

Family environment is the first stage to teach emotional skills. This teaching is conducted with parents' speech and behavior with children as well as children's patterning of parents' emotional skills. This teaching makes children successful in identifying their feelings and expressing their emotions properly, finding methods for calming themselves and controlling unpleasant feelings as well as understanding others' feelings and sympathizing with them. For this teaching, parents themselves should have required competency and EQ. Individual's success in education whether at school or at university is not only relevant with his intelligence, but it is relevant with emotional and social skills of EQ such as having sufficient motion, ability to wait, obeying orders and shock control, skill of wanting help from others and expressing emotional and educational needs. 


\section{SPIRITUAL QUOTIENT}

There exists an inverse relation spirituality and psychosis in a way that as an individual's spirituality is higher, his calmness is also higher. Certainly, calmness does not mean being without concern and pain, but the concern and pain of the spiritual intelligent is greater and deeper than others. The concept of spiritual quotient includes a kind of compatibility and behavior of solving problems that includes a level of development in the different cognitive, moral, emotional and individual fields and contributed to the interaction and coordination with the world around and achievement of an individual's internal and external consistency (Animasahun, 2010). This information provides individuals with a comprehensive view concerning life and the all experience and events around them and enables them to have a new interpretation of their experiences and identify religious principles deeper. It seems that SQ goes beyond individual's physical and cognitive relations with his surroundings, which are affected by a general view. Individual can give this intelligence grater meaning and personal value for reformulating and reinterpreting his experiences (Nazel, 2004). SQ is an ultimate intelligence that shows meaningful and value issues to us and solve problems related to them. SQ may be observed in the form of compassion, paying attention to all awareness levels, mutual sympathy, mercy and benevolence. Individuals who have a high SQ, have sublimity capacity and high inclination to awareness. They have the capacity to assign part of their daily activities to spiritual deeds and show virtues such as generosity, thankfulness, humility and compassion from themselves.

\section{SQ AND EQ IN ISLAM}

EQ is criticized owing to its scholar approach. Zohar and Marshall are two famous characters who suggested a new phase of quotient that includes Emotional-Spiritual Quotient (ESQ) in the early twentieth century. These two scientists consider SQ placing an individual's deeds and behavior in a wider and richer sense. They define this aspect of quotient as the awareness of the nature of values. This quotient deals with judging the meaningfulness rate of deeds and individual's way of life. In ESQ, SQ is the ability to give spiritual meaning to the individual's thinking way and behavior as a way for performing gratitude of God's qualities and our duties to His infinite essence. SQ act as a tool for increasing both emotional and spiritual interests that brings about happiness and peace in an individual's daily attempts (Abedifar \& Sorkhi, 2008). Although the main idea of the term Spiritual Quotient is not in Islamic field, this does not mean that its identity is not ignored in the Islamic works. What is clear is that by a brief research in the Quran, it can be found that SQ is the very faithful man who moral sublimity has been manifested in his character and deeds. Islam as a world view and way of life in the frame of Islam, faith and human promotes the individual's spiritual quotient that provides the constructive systematic mechanism of the human character and management of feelings and spirituality based on the Quran and tradition as the main principle of life in the relation between human and God. EQ and SQ lead human towards spiritual enlightenment and show ways for being free from bonds and limitations that make heart dark and suppress the inner voice. Perhaps, the closest word to the concept of SQ is heart spirituality. Hearth is a spiritual organ, which is the foundation of human character. Ghazali had preferred to use the word "heart" for self in all his religious and moral writings. In the literature of Sufism, hearth is defined as one of the divine favors attached to the physical organ that keeps the inner truth of human and without it, human cannot be different from other animals (Marshall \& Zohar, 2005). 
Tus, the words "reason, hearth and soul, which are mentioned directly and indirectly in the Quran, mean that reason, hearth, soul and psyche respectively all refer to this unique spiritual essence. Hearth is described as the battlefield of reason and self. Heart is the creator of all feelings, desires and dreams. Purified hearth is able to understand belief issues that can contemplate Nature to obtain piety. An individual with potential heart quotient receives and accepts revelation conditions and inspiration of God's orders (Danah, Marshall \& Zohar, 2000).

When psycho-spiritual health occurs that heart is awakened and bright gradually with individuals' awareness from God's orders. The Prophet (peace be upon him) says "in the inner of human, there is a physical part that when it is wasted, the body would be rotten and when it is healthy, the body remains healthy (Badri, 2000).

ESQ includes five fields (Abdifar \& Sorkhi, 2008):

First, intellectual intelligence that is relevant with accepting divine knowledge. It is for detached humans. Logical though is among its characteristics.

Second, EQ that is concerned with the ability to encounter with shocking emotions. It makes individuals to act carefully and patiently and keep their head when they are confronted with problems.

Third, Moral intelligence that is related to human's relation with the world that includes persons who act properly and morally so that people have good feeling about him.

Fourth, SQ that is the very heart quotient, information relevant with inner characteristics beyond human's thought.

Last, religious intelligence that is concerned with the relation with God and religion. This intelligence guides the individual to the right path in order to make him behave in a way resulting in faith and piety.

\section{DIMENSIONS OF ESQ}

SQ integrates all existence dimensions of human's life and guides them so that he lives purposefully. ESQ creates self-making, self-purification, self-control, self-conscious, discipline, spiritual puberty, spiritual commitment and close relation with God resulting in individual and social power, what is advised in the Quran and the Prophet (peace be upon him) has emphasized on it. This paper limits it discussion range in several outstanding aspects that focuses on self-control, moral teaching concerning character-making.

\section{Self-control and Emotions}

Character includes distinct mental and moral characteristics in an individual and if an individual shows a behavior in accordance with reason and logic, he has a good character. SQ, in purifying individual's character depends on the ability of self-control. Achieving self-control needs spiritual puberty and training that teaches the faithful people patience in achieving immediate bounty and pleasure so that the individual may achieve a higher level of spiritual, intellectual or physical pleasure. Achieving this level of knowledge and ability in controlling our feelings requires the knowledge to how control our inner power.

\section{Self-control and Individual Ability}

The power of inner self-control produces an individual power that is a series of character qualities that is considered an extremely important aspect of ESQ. Individual power shows 
strong and clear principles of life in confronting with challenging environment. An individual with his individual power is able to produce reactions that is the most appropriate life principles for him. Self-control is indispensable for the existence of human. This is only one aspect of the concept of patience. Patience is the key of EQ. the concept of self-control with patience is extremely wide and comprehensive. Patience develops individuals in many dimensions and grants them superior morality and provides a beautiful and peaceful life that cannot be compared with the life of those who behave far from faith in God. In addition, faithful people are promised to the abundance of bounty in lieu of their patience (Ginanjar \& Agustian, 2005).

One of the important factors that prevents from intelligent deed is that their behavioral and intellectual shock bring about anger that makes mind silent and puts the individual under pressure to act without thought. Ina similar way, feelings and emotions such as fear, stimulation and anger might make the individual far from away of logical and intelligent thought. Therefore, faithful people who are always patient, God recommends to them to acquire the biggest bounties, which are knowledge and intelligence in order to be far from extreme anger and emotions, which are the result of lacking this intelligence. This allows them to manage their all deeds peacefully, gently and intelligently and make decision in the most useful way. Human's soul can be both healthy and unhealthy as its body can be so.

When soul is healthy, he leads all his strength without any psychic signs such as anger, fear, depression and other disease-like forms (Badri, 2000). In the lack of ESQ, there is no control on the individual's inner incompatible power. This in turn, develops negative thought or defective thought and results in emotional disease-like habits such as anxiety, anger and sorrow, which is the main cause of psychic disorders.

Taqwe and Self-awareness

SQ enables us to control our inner thoughts that creates observable human deeds and behavior. Inner mental faculty, which is not in accordance with destructive thoughts and negative feelings and always seeks to transfer to a positive state that develops Taqwe and selfawareness that is the foundation of ESQ based on the following principles:

1. Relation among thoughts, feelings and reactions

2. Understanding of the consequences of inappropriate choice

3. Identifying our weak and strength points

4. Seeing ourselves positive, but with a real view

Furthermore, self-awareness includes the ability to be more cognizant of our feelings at their occurrence time. Self-awarded individuals are those who trust in their feelings more than other do, are superior leaders and attempt to be compatible with others. Self-control power creates the ability to manage feelings and can manage feelings appropriately (Michael, 2001). Individuals who have ESQ experience positive constant states of satisfaction and wealth in comparison with those who have negative temper and feelings such as hopelessness, depression and anger.

Thus, individuals with emotional consistency and character clearness should use this ability to be compatible with conditions and development of a way for confrontation with more steady stress. They manage their feelings intelligently for leading their thought and behavior that bring about peace, courage, self-confidence and self-positiveness developing a sense of hope and eliminating hopelessness (Irene, 2005).

Real Muslims have the greatest Tawakkul in God and do all necessary measures to solve their problems, while they deliver their heart to God completely and make their mind busy with the best solution for solving problems based on what God has granted him in terms of material and psychic capacities. 
The close relation between Tawakkul and happiness is clear. The individual may be poor, but is happy and hopeful based on his Tawakkul, he may suffer from incurable disease, but accepts all what has been considered by God and therefore, the individual is happy based on Tawakkul. In other words, it is believed that everything that can happen for us is good, thus, there is no adversity in its real sense, while it would be painful.

\section{MERCY AND INTERPERSONAL POWER}

With ESQ, the individual obtains emotional balance as a developing resource of interpersonal and intrapersonal skills for making a good character for developing high human relationships at social level. The dimensions of intimacy, forgiveness and compassion enable individuals to reinforce brotherhood and connection in relation to themselves and others. Recent studies show that when our heart is filled with God's compassion, we are able to manage others' feelings and consequently our social competency would be improved. This dimension is extremely important for developing an effective leadership and interpersonal relations. Making a relation continued requires being aware of our and others' feelings and emotions. With such type of awareness of a vital dimension of ESQ, individuals are able to be flexible and make effective relationships with others. In modern psychology, this issue is recognized as "intimacy" that basically refers to others' feelings and concerns. Moreover, it respects differences in how the individual encounter with different feelings regarding affairs. Therefore, intimacy includes others' understanding and helping them in developing their individual capacities (Ebrahimi, 2007). This dimension is concerned with philanthropic behavior such as making attempt to understand and help others in solving their problems. It also includes qualities such as being a good listener, being certain and courageous instead of being anger and passive, constructive management of conflict and teaching the art of cooperation. This characteristic is the core of a relationship and helps people to cooperate for a comprehensive and constructive relationship and teaching the art of cooperation. Studies indicate that individuals who are superior in this skill, are inclined to have a good performance in what depend on interaction with others, because they are social stars and models.

Emotional skills is extremely important in social relationships so that it is considered a key for understanding others' feelings in nonverbal communications such as voice tone, gesture and face expression. Compassion is the ability to identify other individuals' feelings that can help us in showing intimacy to people. From emotional perspective, individuals' expression are interpreted simpler. All individuals have similar emotional needs regardless of their gender, religion and culture that are created based on different needs. They are ones who are able to soothe their feelings particularly regarding important social issues.

ESQ creates positive qualities like forgiveness, love, patience and intimacy in interpersonal relationships that is granted as one of the biggest divine bounties to humanity. Human's divine nature is in a way that always enjoys love and to be loved. Forgiveness is attached to tolerance and has a close relation with it. Forgiveness and tolerance as a dimension of ESQ is a dynamic and powerful interpersonal power that can enhance communicative skills.

This dimension of ESQ is the main principle in the individual's social relationships with those who are higher, equal or lower than his status and he should tolerate harming motivations as much as he can and learn experiences and ignore bad things. Spiritual not only regards the individual's relation with God, but also includes social dimensions. Human's relation with his creatures is rooted in human's moral attitude with his mankind. This is a reality that all humanity are the creatures of one creator and God's willing is the existence of compassion, 
kind and fair humans for curing and living with each other (Ary, 2005). Humans' relations should reflect the high quality existence of God. Love of God should be shown in love of humanity. If someone can obtain a high quality relation with God, he can be the real winner and the main foundation of morality would be manifested.

Therefore, ESQ focuses on human's growth that directs human's life and can cure his pains and finally guide our feelings from movement in a limited level to a higher level of spirituality when we will return to our original nature.

\section{CONCLUSION}

The aspects of ESQ in Islam are not a new issue. The Prophet and his companions" life is filled with aspects of ESQ that are the foundation of Islamic ethics. With the guidance of the Quran and the tradition, moral virtue discusses the development of good character that is often a process of confronting with individual feelings and others' emotions that pave the way for psycho-spiritual management, which is focused on making a focused character.

Self-purification, self-control, discipline and order, spiritual puberty are resources and mechanism of making ESQ that are the consign components of moral virtue and should be transferred to the direction of character balance and proper interpersonal relations. It emphasizes on the importance of the development of spiritual aspect of human's working morality to improve the capacity of human resources that in turn stresses on the general cooperation. The understanding of spirituality as a kind of intelligence develops the psychological concept of spirituality and makes its relation with the cognitive and reason process such as achieving goal and solving problem possible.

Finally, this is the main function of educational system that deals with the development of ESQ in the direction of Islamic ethics. Education is the main goal of Islam in order to develop soul, heart, self, mind and body. Most of educational systems are focused on the scientific aspect and ignore spiritual and moral aspects. Students seek to acquire objective knowledge, while, they overlook mental knowledge in order to promote their thought and financial productivity at the end of their education so that the performance of education which is making attempt to make individuals who possess moral honesty, spiritual values and respect to each other is ignored.

Islam has considered SQ implicitly. For example, factors affecting SQ in the Islamic texts are piety and conducting daily affairs such as contemplating the Creation, fasting and praying. Teenage is the best time to develop positive feelings and to control negative feelings and teach moral skills, because teenagers seek their own identity and future character in this period. SQ affects individual's life quality considerably and it should be mentioned that teenage is a critical period that needs to particular teaching to achieve a clear future and encounter with problems. As much as individual in his life affairs consider God's satisfaction in addition to his knowledge and awareness and develop the ability to distinguish right from wrong, he would create the ground of the growth and development of ESQ in himself.

Some challenges that their studying is felt include:

○ How much cultural environment, family, instructors, teachers, friends and people's religion are affected by the development of SQ?

- How required interferences for increasing SQ using different theories could be presented, measured and ho their validity could be determined? 
- How could we achieve the investigation of the relation of SQ by accurate understanding of religious text and solving spiritual problems as well as insightfulness for solving moral difficulties?

○ How a necessary environment could be created for the development of SQ in managers?

\section{References}

[1] Faramarzi, S. Homaie, R. \& Husseini, M. (2009). The examination of the relation between EQ and SQ of university students, Journal of Islamic studies and Psychology, No. 5: 17-24.

[2] Toranloo, H. \& Mirghafoori, R. (2007). The investigation of the relation of Believing in religious Islamic teachings and EQ, Scientific \& Research Journal of Modern Religious thought, No. 11.

[3] Abedifar, F. \&Sorkhi, Z. (2008). The relationship between spiritual intelligence and personality characteristics among individuals between 19-50 years old in the city of Sari. M. A. thesis,

[4] Animasahun, Rotimi A. (2010). 'Intelligent Quotient, Emotional Intelligence, and Spiritual Intelligence as Correlates of PrisonAdjustment Among Inmates in Nigeria Prisons', Social Sciences, Vol. 22, No. 2.

[5] Ary Ginanjar Agustian. (2005). The Islamic Guide to Developing Emotional Spiritual Quatient, Arga Publishing, Jakarta.

[6] Badri. M (2000). Contemplation An Islamic Psycho-spiritual Study, International Institute of Islamic Thought: London.

[7] Becker, Irene (2005). 'Smart and Fast are not Enough, The Importance of Increased Emotional Intelligence to the Success of Your Mediation Practice and Your Life', http//:www.justcoachit.com.

[8] Beckwith, Jon and Michael Carson (2009). 'Race, IQ and Genes',http://www.els.net/WileyCDA/ElsArticle/refId-a0005689.html.

[9] Berman, Michael (2001). 'Developing SQ (Spritual Intelligence) Through Elt', Elt Newsletter, http://www.eltnewsletter.com/back/April2001/art572001.htm.

[10] Bleazby, Jennifer (2006). 'Autonomy, Democratic Community, and Citizenship in Philosophy for Children, Dewey and Philosophy for Children's Rejection of the Individual/Community Dualism', Analytic Teaching, Vol. 26, No. 1.

[11] Conscious pursuits (2005), spiritual intelligence, Conscious Pursuits, inc, all rights reserved.

[12] Carlsson-Paige, Nancy (2001). 'Nurturing Meaningful Connections with Young Children',Reclaiming Children and Youth, Vol. 10, No. 1.

[13] dissertation, Institute of transpersonal psychology.Bahrami, F.; Malekian, H. \&Abedi, M. (2004). To study and compare the approaches of increasing responsibility taking in students of guidance school grade of Esfahan city.

[14] Ebrahimi, A. (2007). Self-belief, an approach in taking responsibility, Journal of Hemayat, 7. 
[15] Fakhry, M. (1991). Ethical Theories in Islam, E.J.Brill: Leiden.

[16] Goleman, D. (1997). Emotional Intelligence, Bantam Books: New York.

[17] Mohd. Nasir Omar. (2003), Christian and Muslim Ethics, Dewan Bahasa dan Pustaka: Kuala Lumpur.

[18] Payam Noor University of Behshahr.Amram, y (2009). The contribution of emotional and spiritual intelligences to effective business leadership.(Electronic version), unpublished doctoral.

[19] Zohar, Danah (2005). 'Spiritually Intelligent Leadership', Leader to Leader, No. 38, http://www.hesselbeininstitute.org/knowledgecenter/journal.aspx?ArticleID=84.

[20] Zohar, Danah and Ian Marshall (2000). SQ: Spiritual Intelligence, the Ultimate Intelligence, London: Bloomsbury.

[21] Zohar, Danah and Ian Marshall (2004). Spiritual Capital: Wealth We Can Live by, San Francisco: Berrett-Koehler.

[22] Zaroug, A.H. (1999). "Ethics from an Islamic perspective: basic issues", The American Journal of Islamic Social Sciences, Vol. 16, No. 3, IIIT, Virginia. 